Holotype.- $\sigma^{7}$, Eastern Harbour, Cape Breton Island, N.S., Canada. (A. G. Huntsman).

A close ally also of Tipula entomophthorae ${ }^{1}$ Alex., which it resembles in hypopygial structures and from which it is differentiated in the bicolored, flagellar segments and the ill-defined, thoracic stripes. It differs from Tipuia angulata Loew and Tipula huron Alex. ${ }^{2}$, in the angulate fascia not rendering the posterior wing-margin. Tipula texensis Alex. ${ }^{3}$ ', has the pale fascia before the stigma.

Respectfully dedicated to Dr. A. G. Huntsman.

\title{
A NEW USE FOR THE AEROPLANE.
}

The Department of Agriculture at Ottawa has discovered a new use for the aeroplane. The Entomological Branch is investigating the mosquito in the Lower Fraser Valley in British Columbia. By using the aeroplane, the country can be surveyed in order to map out the swampy areas and other breeding places that are readily located in photographs taken from over head, according to a statcment by Dr. C. Gordon Hewitt, Dominion Entomologist, that appears in the October Agricultural Gazette. The aeroplane was used in making a comprehensive survey of the complicated water system of the Fraser River and the adjacent bodies of permanent and temporary water in that district. A flight reported by Dr. Hewitt has demonstrated the possibility of using this machine also for making surveys of timber that is being killed or has already been destroyed by various insects. Its use, it is believed, will help very greatly in the entomological work with various insects being carried on by the Federal Departiment of Agriculture.

\section{THE HOUSE CENTIPEDE, CERMATIA FORCEPS RAF. IN MONTREAL.}

A specimen of this Myriapod was found in a classroom of Goltman's Business College on St. Lawrence Boulevard (corner of Sherbrooke Street) on July 22, 1919, and was sent by Mr. Robert Goltman to me for the Redpath Museum where it was seen by Mr. A. F. Winn. It was kept alive feeding slightly upon house-flies until August 19th, when, by an unfortunate accident, it escaped. The species is mentioned in Comstock's Manual (p. 46) as "often found running on the walls of houses, especially in the Southern States." It was observed in Albany from 1870 onwards by J. A. Lintnar, but this is believed to be the first record of its occurrence in Montreal. Lintner's account of its cleaning habits was confirmed; when cleaning the hinder limbs the body is bent sideways. The appendages of one side are cleaned in succession, beginning with the antenna.

The occurrence of this Myriapod in Canada has been recorded only once previously, a specimen having been taken in Toronto. (Can. Ent., XLVI, p. 219, 1914.)

Arthur WiLley.

Two other specimens of the housc centipede from Toronto have been sent me to for determination sincc the record cited by Prof. Willey was published.

E.M.W.

1. Can. Ent., Vol. L, p. 385.

2. Ibid, Vol. L, p., 66 .

3. Ibid, Vol. XLVIII, p. 48. 